\title{
To the Study of Reflection of Cultural Identity Processes in the Russian Art of the $16-17^{\text {th }}$ Centuries
}

\author{
Natalia N. Parfentieva* \\ Southern-Ural State University \\ 76 Lenin Str., Cheliabinsk, 454080, Russia
}

Received 02.06.2018, received in revised form 11.06.2018, accepted 25.06.2018

\begin{abstract}
The article reveals the ways of studying the features of the core concepts of Russian cultural identity representation in the Russian art of the 16-17th centuries, considered in its continuous dynamic and dialectical development at the key stages of formation and transformation. The relevance of the study stems from the fact that among a significant number of works on the problems of Russian art of the late Middle Ages and the beginning of the New Time, there are no special scientific works in which this topic would be considered as the main one. It is particularly important to define what the fundamental (archetypal) grounds of cultural identity is, how it is transformed at a turning point of history. The author suggests methods and approaches to solve the problem. One of the most significant scientific approach is the integrity of the investigation. It consists of comprehension of sustainable historical core of cultural identity and its embodiment in the art in all the chronological stages of the study period. The factor of identity stands out as a crucial element, synthesizing various determinants, that act in the development of art. The novelty consists of the authors' identity reflection concepts in art and the use of a number of authors' techniques to reveal semantic and stylistic formula of identity embodiment in the works of artists. The author gives a justification for the application of the inter-textual method of identifying the essential foundations of cultural identity, the textual method of structural and formulae analysis of the musical hymnographic works of medieval art, the elementstructural method of research of manuscript ornamentation art. The solution of this problem will complement modern scientific ideas about cultural identity in the art and spiritual culture of Russia.
\end{abstract}

Keywords: cultural identity, Russian art, Russification of Byzantine cultura, Russian late Middle Ages, Ivan IV the Terrible, scientific methods and approaches.

DOI: 10.17516/1997-1370-0296.

Research area: culturology.

Cultural identity relates to the phenomena that always attract attention and remain in demand for the in-depth research. The problems of the study of this phenomenon should be attributed to the number of contemporary world challenges. In Russia a considerable academic interest of cultural identity comprehension was initiated by a systemic crisis that erupted in the country in the last quarter of the twentieth century. A radical destruction of the ideological paradigm and the choice of the "pro-Western" vector of development affected all aspects of life of society and personality, thus arousing the associations with the Europeanization in the time of Peter's

(C) Siberian Federal University. All rights reserved

* Corresponding author E-mail address: parfentevanv@susu.ru 
reforms. The issues of keen research interest in contemporary humanities are the search for identity, the philosophical debate about Russian peculiarities and destiny.

Solving the urgent problem of Russian national identity threats in connection with its crisis in Russian society, the modern humanities scholars actively explore various aspects of national and cultural identity formation processes. Historically, researchers reveal the influence of the Orthodox factor for the formation of Russian statehood and the mental factor in carrying out liberal reforms, trace the changes that have occurred due to national self-identification in economy, technology, state-building, social psychology. Nevertheless, systematic and deep analysis of similar changes in the field of art, which is a very promising area of research, has just begun.

How original are local arts and to what extent are they rooted in the historical perspective? What were the special aspects of cultural identity formation and development in the Russian art? These questions remain largely unresolved. It is particularly important to establish what is the fundamental basis of the cultural identity and how it is reflected in the Russian art works, how it was transformed during the particular historic period. The proposed research deals with the reflection of cultural identity processes in the Russian professional art in the $16-17^{\text {th }}$ centuries.

In science, the theoretical aspects of the problem of "constructing" the phenomenon of identity in works of art and in cultural texts, as well as the methodology of such studies, are at the stage of initial comprehension. Let us note in this connection the works of scientists representing the Krasnoyarsk school of cultural studies: (Koptseva, 2013; Kolesnik, 2016 et al.). Among the classical works that developed a number of fundamental issues of the historical self-consciousness of Russians, first of all, we call the studies of Russian philologists and literary scholars - D.S. Likhachev, B.A. Uspensky, Yu.M. Lotman. (Likhachev, 1986; 2007; 2015; Uspenskiy, 1998; Lotman, Uspensky, 1982). The works of these outstanding scientists still have not lost their relevance and continue to provide an opportunity to refer to issues of the manifestation of the Russian national idea in culture and art.

Certain aspects of the formation of nationalhistorical thinking are reflected in a number of historical studies (Plyuhanova, 1995; Klibanov, 1996; Usachev, 2015). The relatively studied area of research within the framework of the problem is the study of the reflection of ideologies "Moscow - the Third Rome" and "Moscow - the New Jerusalem" in the architectural monuments, culture and art ${ }^{1}$. Recently the problem has been studied on the material of Russian musical hymnographic art (Parfentyev, Parfentyeva, 2016; Parfentieva 2016a; Parfentieva, 2016b).

The problem of Russian national identity is one of the most rapidly developing areas of the Anglo-American Russian studies. In their works the British and American researchers of the $21^{\text {th }}$ century conduct the methodological searching, the interdisciplinary approach is basic, which involves the study of the problem including through the prism of literature, architecture, music, cinema and other arts in the post-Soviet space $^{2}$. The foreign researchers have also given attention to the overall processes of formation of national identity in art. $^{3}$

It should be noted that the representatives of foreign science did not aim to reveal the concepts of the cultural identity contained in the Russian art of the $16-17^{\text {th }}$ centuries. Nevertheless, some Western scholars (e.g., professor at the University of Birmingham Maureen Perrie, professor of history at Harvard University Marshall Poe) disclosed some theoretical questions of origin and spread of concepts of the national-political development of Russia, directly influenced on the 
processes of cultural self-identification (Perrie, 2014; Poe, 2000). In addition, the prominent American scholar James Billington and his British counterpart Peter Duncan showed the parameters of political ideas functioning in Russian culture (Billington, 1998; Duncan, 2002). However, these historians interpret the processes of development of Russian national culture very generically, they do not introduce new sources and with rare exceptions do not consider the development of spiritual culture on the example of the particular works of art.

Thus, the problem of reflection of Russian identity, its structure and the genesis in art, the determination of the basis of its understanding through the artworks of the period under study is practically unexplored, which puts this issue on the current level. The relevance of the proposed research in terms of the creation of new and development of existing trends in art criticism is due to the fact that among the large number of works, considering the problem of Russian art, there are no special scientific ones in which the art of study period would be represented as the basis for the review process of formation and development of cultural identity.

In our research this phenomenon is understood as the identification of individual to society in such typical sociocultural measurements as language, mentality, ideology, regulatory and typical behavior, sociocultural values. At the core of cultural identity is the need for integration through familiarizing with the base values and goals for a given society, expressed by semantic symbols. They are filled with a definite content through social and cultural context, including the special characteristics of reflection in art. It is important to reveal these characteristics, to show the original features of reflecting the Russian cultural identity in the art of the period under review on the examples of representative art works.
Let us turn to to reveal the main ways, the nature and the degree of the historical process influence on the formation of cultural identity in Russia (forming of political ideology, growth of national self-consciousness, influence of external cultural borrowing, etc.) on the outstanding masters' artistic thinking.

As already indicated, chronologically the problem is limited to the $16-17^{\text {th }}$ century. It is determined by the following historical context. The main factors of acceleration of the Russian cultural identity formation were the center of Orthodoxy moving from Constantinople enslaved by the Turks to Moscow, the Russification of Byzantine cultural heritage in Russian church art, the embodiment of messianic ideas of "Moscow the Third Rome" and "Moscow - New Jerusalem" in art and culture. The most important historical prerequisites to the emergence of these ideologies were the fall of Constantinople (1453), the overthrow of the Mongol-Tatar yoke (1480), the completion of the unification of Russian lands around Moscow. Already during the reign of Ivan III and Vasiliy III, these events were perceived as the steps in the displacement of the center of the true faith (Orthodox) in a new "capital city".

The formation of the young Russian state, its appearance in the international arena, refusal of the leading European countries to recognize the tsar title and the tsardom itself stimulated inside the country the search for its place in the world. In the consciousness of Orthodox Christians of Moscow tsardom of Ivan the Terrible time the image of Byzantium was presented in the form of two symbolic images: Constantinople - as the New Jerusalem, the holy, theocratic city, and at the same time as the New Rome - the imperial capital of the world. Then these ideas were transferred to Moscow: "Moscow - the Third Rome", "Moscow - the New Jerusalem". In the $16-17^{\text {th }}$ centuries these messianic ideas served as the basis for 
the search for the Russian state identity. We find their manifestation and embodiment in architecture, hymnography and church chanting art, icon painting, other arts. Ancient layers of professional art that carry the Byzantine origins are conceptualized as the archetypal foundations of the cultural identity. Thus, the messianic ideas played the significant role in the formation of cultural identity and were refracted in art, contributing to spiritual elevation of the Moscow State.

As is known, the historical role of Tsar Ivan the Terrible consists in the completion of the construction of united centralized state - the Moscow tsardom, initiated by his predecessors. He participated in the construction of Russian identity as a dynamic continuum, built on historical memory, painted in religious colors. The tsar set out the accents and actualized those aspects of the historical past that corresponded to his views of the ruler. The dominant idea was the universal Orthodoxy, the stronghold of which the Orthodox sovereign state - Moscow Rus was remained. Russia took the cultural heritage of Byzantium and the South Slavic states and preserved it. Messianic ideologies - "Moscow New Jerusalem" and "Moscow - the Third Rome" developed on this basis.

The sacralization of power, the legitimization of its right to violence against external and internal enemies in the conditions of the existence of the state as a "besieged fortress" are also closely related to the idea of the state rooted in the world of Sacred History, Orthodoxy. All this constituted the coherent foundations of Great Russian selfconsciousness during the period of the Moscow tsardom. They formed a community - the Russian people with religion, language, traditions, history. The Russian people's need for positive selfesteem was realized (they are heirs and guardians of the true faith under the protection of a strong state). In this context, the idea of great-power becomes dominant for the formation of identity. This is confirmed by an analysis of the literary heritage of Ivan the Terrible, which carried out the reception of the historical past in the spirit of Orthodoxy as a key factor in the national identity of the Moscovy. Such historical memory has become the central resource of collective selfdetermination, political legitimization and social mobilization.

Tsar Ivan actively worked as a writer and publicist: he was the editor of the official chronicle of his reign and a noted lover of book culture (Likhachev, 1986; Shmidt, 1984). In his opinion, "his grandparents and parents" had inherited the throne and guardianship of the Orthodox faith from the "Emperor Constantine, first in piety" (Lurie, 1979: 12-13). As such, he took as his example not only the policy of the Byzantine emperors to strengthen the power of the sovereign, but also their spiritual activities. The creation of hymnographical works had a special significance in the tsar's spiritual life. These works include, for example, his "Canon of the angel, the formidable voevoda" (Likhachev, 1986) and the "Troparion on the bringing of the relics of the Grand Duke Michael of Chernigov" (Ramazanova, 1988). It was noted in Russian and foreign sources that Tsar Ivan knew musical neumatic notation and sang with the court choir with pleasure. The Terrible revived the tradition of Byzantine emperors who created musical works as a powerful tool of ideological influence (Parfentyev, Parfentyeva, 2016; Parfentieva, 2016a; Parfentieva, 2016b) .

The evidence of cultural identity existence lies in its implementation in the professional church art of the $16^{\text {th }}$ century. Note the most representative works in this context: Moscow Cathedral of the Intercession on the Moat (St. Basil's) with its Jerusalem Chapel, the icon "Blessed Host of the Heavenly Tsar" from the Assumption Cathedral of the Moscow Kremlin, 
the cycle of neumatic (znamenny) chanting sticherons of Ivan the Terrible authorship dedicated to the Vladimir Icon of the Mother of God and others. The canonization and raising to the rank of an all-Russian worship of more than 40 Russian saints in 1547 and 1549 years has become another indication of the development of consciousness, which caused a surge of creative activity and securing of all-Russian canon in hymnography, iconography, church music, other forms of art. The principles of creativity, rooted in the art of Byzantium, went through a period of Russification. Such Byzantine canonical principles as creativity, based on the prescribed patterns ("similarity"), consecrated by church tradition of Orthodoxy, formulae structure, slightly varied forms of interpretation of formulae were refracted on Russian soil and flourished in the professional art of the $16-17^{\text {th }}$ centuries.

Church art of "great-style", development of the authorship, the formation of art schools as the special directions of Russian art, its professionalization, reforming in the era of tsar Alexei Mikhailovich (Romanov), have prepared the transition to the new Russian art with its common European features. As once the art of Byzantium had provided a basis for the development of Russian ancient and medieval professional art of written tradition, also the Western influence has found a fertile ground for the development of Russian art in New Time.

The traditions of Russian art of the $16-17^{\text {th }}$ centuries, some constant core values and traits, features of artistic mentality have persisted for further historical development. They are defined as fundamental, archetypal bases of the cultural identity, which was clearly reflected in the arts during the period of the Moscow tsardom, when it was formed. The Orthodox religion acted as a dominant trait, a crucial factor of identity. The reforms, undertaken by Peter the Great, could not eradicate it, in spite of a sharp turn in the direction of the Europeanization of art.

Before the reforms of Peter I there was a monoculture, which reflectes the cultural identity, based on Orthodox (Byzantine) traditions. In the period of his reforms implementation it disintegrated, became ambivalent and sometimes multi-layered. This happened due to the secularization of art, borrowing its Western forms of baroque style. There was a gap between the elite, which had joined the Western culture, and the other lower strata of society, preserved old foundations.

Existing research results show that the formed cultural identity, having undergone a cultural transformation in the era of Peter the Great, was preserved, adapting radical innovations. This is the clearest manifested in the resistance of the Old Believers to these innovations and preservation of archaic cultural foundations by them as the guardians of the "ancient piety". These bases have been transformed in the official church art, but retained the high status of the sacred pattern, the archetypal foundation of the canonical Orthodox art. They were pushed aside in the new genres of secular art, but still served as a support for the further development of identity in new historical conditions.

Thus, the specific nature of reflection of Russian cultural identity in art is manifested in continuous development, adaptability to new influences, in a special the type of Orthodox spirituality, in means of artistic expression, in respect for the past and orientation to the historically established cultural artistic archetypes. Despite the radical Europeanization in the time of Peter the Great Russian art had saved the national character. Cultural identity, transformed in the art of the official Church, was given a new interpretation in the genres of New Time art.

The study is directed to disclosing the Byzantine origins of the cultural identity in their 
reflection in the ancient layers of professional religious art. They are explained as the archetypal bases for further development of this identity, as a kind of constant core preserving continuity at all stages of historical development. Professional art of Moscow Tsardom of $16-17^{\text {th }}$ centuries belongs to the Orthodox Church tradition, and bears the generic features of Byzantine influence. Formation of Russian cultural identity, the emergence of its own artistic originality is defined as a "derivative" originating from the archetype.

Formed cultural identity of the Moscow tsardom had prepared the transition to new stylistic transformations, to Europeanized art of the $18^{\text {th }}$ century. For the first time the study present concept of cultural identity embodiment in its historical and cultural development in the Russian art, which covers the most important periods associated with the Russification of the Byzantine and the mastering of Western European traditions. Solution of these problems will open up further ways to study the basic theoretical aspects of Russian cultural identity in their relationship, will give a holistic view of the most important events in the history of Russian art in the context of the formation of identity, will complement modern research visions about art and spiritual culture of Russia in general.

One of the most significant scientific approaches in its realization is the integrity of the investigation. It consists of cultural identity historic core comprehension and its embodiment in the art in all the chronological stages of the study period. Therefore, the study focuses on using different modern methods of investigation. Their choice is caused by the necessity of a deep and comprehensive theoretical understanding of the problem, which is multi-level. The factor of identity stands out as a crucial element, synthesizing various determinants, that act in the development of art. It is a necessary condition for the integrated comprehensive approach of the research.

In order to characterize Russian masters's creation in the context of identity reflection search point out similarities and differences with the Byzantine heritage (16-17 $7^{\text {th }}$ centuries) and the preservation of Russian traditions in the domestic arts of Europeanization period. The integrated approach gives an opportunity to reveal the historical and stylistic aspects of the cultural identity phenomenon, to characterize the reflection of stable ideas in the crucial, key periods of Russian history.

The sources of archetypal foundations of identity research include $12-17^{\text {th }}$ centuries. The archetype of identity is investigated on authentic works of art, manuscripts, including musical, iconographic originals, that demands of special historical research, textual study approaches and methods. Multidimensional nature of the research involves a multidisciplinary approach aimed at the depth of understanding historical, ideological, and stylistic factors, as well as artistic achievements in different kinds of art. Besides, the integrated approach consists of the fact that the problem field of the research under consideration is based on the synthesis of arts, which is caused by the synthesis of genres (musical-hymnographic artworks, church architecture, hymnographic sources of iconography etc.). Thus, the integrity of the study is determined by versatility and multi-level character of the issue, by multidimensionality of its research. It suggests the need to study the most important representative sources for the purpose of revealing the problem implications. The phenomenon of identity will be fully considered in the different chronological periods of its existence, in the works of outstanding art masters who embodied it. The following scientific methods will guarantee the required depth of the research: a systematic, comparative, structural- 
typological, contextual, genetic typological, method of modeling and others approaches.

From the point of view of art criticism it is necessary to use the method of integrated, or holistic, analysis of artwork, including stylistic and structural-functional approaches. This method involves the analysis of artwork form in combination with the study of all components of a whole in their interaction and development. Within the framework of the method is supposed to clarify the historical-stylistic and genre prerequisites. This is necessary for solving the most important task - to disclosure the image of artwork as a resource for formation of identity, as a socially significant phenomenon in the fullness of its historical ties. This type of comprehensive analysis is at the junction of the theoretical and historical art studies.

By using the general scientific semiotic analysis method, aimed at revealing of signs and symbols, by which the identity being implemented, the ways of these signs and symbols functioning in the space of culture will be investigated. The use of inter-textual analysis allows recreating the identity model of Russia Peter's time, supported by the sign system consisting of the images, symbolically expressing of the present and future success of Russians. These system reflects the subjugation of marine element, the comprehension of the various sciences, the realization of large military and political capabilities, as well as characterizes Russia as the European and Christian sovereign state, the successor of the great powers and the peoples of Europe (Rome). Thus, with the help of semiotic means of cognition the most important part of the Russian culture communication field of the first quarter of the $18^{\text {th }}$ century will be decoded, the possibility of a new artistic language in the formation, transformation and transmission of identity will be determined. Analysis of works of art and architecture to reveal in them secular and religious components of the "Russian idea" is very productive with the use of iconological method, studing the historically conditioned imagery and symbolic content of artworks, worldview attitudes, "cultural symptoms" of era.

In its historical part the study is based not only on the semiotic means, but also on the classical methods of historical scholarship historical genetic, historical - cultural and others. In the first place they are used for showing the social conditions of the masters' activity, their worldview attitudes, means of "mental recognition" by the recipients of the images, laid down in artworks etc. The study will conducted on the basis of archival documents and the mass of published sources (such as of personal origin, and record keeping) using the existing in historical science and art complex of source research methods.

Development of scientific methodological principles, which allow the most accurate representation of the artists' work in the embodiment of the cultural identity is in a formative phase. Let offer methods of studying issues for obtaining the most accurate results, which are approved by the author of the article.

The first of these is the method of structuralformulae analysis of ancient chants. It has been tested in the study of the phenomenon of ancient professional church-singing art (Parfentjev, Parfentjeva, 2008). Use of the method as applied to the chanting art involves of detecting of the most ancient neumatic recording of the studied chant. Then the chant variants of modification based on this archetype are revealed throughout the centuries as "derivatives" of the archetype, and then - in the form of versions of authorship in the $16-17^{\text {th }}$ centuries. The last ones are decoded (translated into modern musical notation) thanks to retrospective method. This translation allows us to carry out the musical reconstruction of author's 
artwork. On the basis of this method there were performed musical deciphering of neumatic texts of Ivan the Terrible's chanting cycles, made their formula-structural analysis, revealed figurative and semantic relation of himnography text and music. In the research of the artworks of the tsar it will be continued to examine the question of musical self-identification of the sovereign hymnographer and raspevshik (composer).

The described method was extrapolated to another problem field of the study - ornamentation art of handwritten book miniatures, which has resulted in solving of the problem of the author's creativity and its cultural identity. Here it was called as element structural method of study of handwritten books ornamental art (the method is substantiated by N.P. Parfentyev).Thus, the method makes it possible to explore the phenomenon of identity in the works of artists brothers Basov's (the middle of $16^{\text {th }}$ - the first third of the $17^{\text {th }}$ centuries). They use the so named "black-letter ornament" - adapted heritage of the European book engraving of Yisrael van Mekenem.

The next author's method, we determined it as an inter-textual method of definig the essential bases of identity, is closely related to the first one. It includes some of the extrapolation approaches for revealing of embodiment of identity searches in the domestic arts: a comparison of works of art from the period under review with the archetype - the most ancient, authentic, leaving in Byzantine heritage sample. The goal is to bring out the phenomenon of cultural identity implementation in the later art works of outstanding masters, as well as the basic ideas of the Messianic spiritual elevation of the Russia, similarity Moscow to Rome and Jerusalem. As well as markers of identity we define the correlation of its searches with such creative principles as "similarity", the formulae structures and formulae variation of the medieval period, the preservation and transformation of these traditions in the age of Peter I. Thus, the method assumes revealing of "Russianness" diversity in the art of period under consideration on the basis of a truly archetype. The identity phenomenon will be determined not only through Russian origins, but also through the correlation with European professional tradition. As a result, the reliance on this method allows defining of semantic and stylistic formulas of embodiment of identity in the masters' art works of the studied period.

Thus, the successful execution of tasks is ensured by the whole complex of used methods and the introduction of new techniques and instruments for the research that will give the most accurate and relevant results. The obtained results will enable to represent the basic theoretical aspects of the problem adequately and give a holistic scientific knowledge about one of the most important phenomena of the of Russian art history, complement the modern scientific visions about identity in art and spiritual culture of Russia.

\footnotetext{
1 The following scientists turned to this topic: A.A. Amosov, A.L. Batalov, S.N. Bogatyrev, A.A. Bredniy, M.A. Ilyin, M.K. Karger, N.V. Kvliwidze, A.B. Konotop, V.A. Kosyakova, I.A. Kochetkov, N.P. Krokhina, M.P. Kudryavtsev, A.L. Lidov, V.V. Morozov, O.I. Podobedova, D. Rowland, D.O. Shvidkovskiy, I.M. Sokolova, V.M. Sorokaty, V.L. Snegirev, B.A. Uspensky, L.S. Uspenskaya, M. Flyer and others.

B. Forest, J. Johnson, J. Cracraft, D. Rowland, J.H. Billington, P. Duncan, S. Franklin, E. Widdis, K.R. Bouveng R.Taruskin, M. Frolova-Walker, C. Brooke.
}

\section{References}

Billington, J.H. (1998). The Face of Russia: Anguish, aspiration and achievement in Russian culture, New York. 269 p. 
Duncan, P.J.S. (2002). Russian messianism: Third Rome, Revolution, Communism and after. London - New-York: Rout Ledge , 255 p.

Klibanov, A.I. (1996). Dukhovnaya kul'tura srednevekovoy Rusi [Spiritual culture of medieval Russia]. Moscow, 368 p.

Koptseva, N.P., Seredkina, N.N. (2013). Konstruirovaniye etnicheskoy identichnosti v polikul'turnoy sisteme [Designing of ethnic identity in a multicultural system]. Krasnoyarsk, 184 p.

Kolesnik, M.A. (2016). Konstruirovaniye russkoy kul'turnoy identichnosti: kontseptual'nyy i metodologicheskiy podkhody [Construction of Russian cultural identity: conceptual and methodological approaches]: dis. ... kand. Kul'turologii. [Thesis of candidate of cultural studies]. Krasnoyarsk.

Likhachev, D.S. (1986). Issledovaniya po drevnerusskoy literature [Studies in old Russian literature]. Leningrad, $406 \mathrm{p}$.

Likhachev, D.S. (2007). Russkaya kul'tura [Russian culture]. St. Petersburg, 440 p.

Likhachev, D.S. (2015). Chelovek v literature Drevney Rusi [Human in the literature of Ancient Russia]. St. Petersburg, 320 p.

Lotman, Yu.M., Uspenskiy, B.A. (1982). Otzvuki kontseptsii «Moskva - tretiy Rim» v ideologii Petra Pervogo (K probleme srednevekovoy traditsii v kul'ture barokko) [Echoes of the concept of "Moscow - the third Rome" in ideology of Peter the Great (On the problem of the medieval tradition in the culture Baroque)]. In Khudozhestvennyy yazyk Srednevekov'ya [The artistic language of the Middle Ages]. Moscow, 236-249.

Lurie, Ya.S., Rykov, Yu.D. (1979). Perepiska Ivana Groznogo s Andreem Kurbskim [The Ivan the Terrible's correspondence with Andrew Kurbskiy]. Leningrad. 1979, 12-13.

Parfentjev, N.P., Parfentjeva, N.V. (2008). On the Structural-Formulae Method of Researching Ancient Russian Chants as Musical-Written Art. In Journal of Siberian Federal University. Humanities \& social sciences, 1 (3), 384-389.

Parfentyev, N.P., Parfentyeva, N.V. (2016). Ivan the Terrible's Stichera: The Idea of Russia's Spiritual Elevation. Quaestio Rossica, 4 (1), 137-156.

Parfentieva, N.V. (2016a). Image of Ivan the Terrible in creativity of the composers: on question of national identity in musical art. In Journal of Siberian Federal University. Humanities \& Social Sciences. 2016, 8 (9), 1903-1909.

Parfentieva, N.V. (2016b). Voploshcheniye russkoy national'noy identichnosti v obraze Ivana Groznogo v muzykal'nom iskusstve [Implementation of Russian national identity in image of Ivan the Terrible in musical art]. In Bulletin of the South Ural State University. Series: Social Sciences and the Humanities, 16 (4), 99-102.

Perrie, M. (2014). Moscow in 1666: New Jerusalem, Third Rome, Third Apostasy. In Quaestio Rossica, 3, 75-85.

Plyukhanova, M.B. (1995). Syuzhety i simvoly Moskovskogo tsarstva [Plots and symbols of the Moscow kingdom]. St.-Petersburg, 334 p.

Poe, M. (2000). The invention of the concept "Moscow - the Third Rome". In Ab imperio, 2 , 61-86.

Ramazanova, N.V. (1988). Tropar' i kondak «knyazu Mikhailu Chernigovskomu: Tvorenie Ioanna, bogomudrogo tsarya, samoderzhtsa rossiyskogo» [Troparion and Kontakion, dedicated to the "Prince Michael of Chernigov: Creation of divinely wise tsar Ivan, The Russian autocrat"]. In Literatura 
Drevney Rusi: Istochnikovedenie: sb. nauch. tr. [Literature of Ancient Rus: Source study: collection of scientific works]. Leningrad, 107-116.

Shmidt, S.O. (1984). Rossiyskoe gosudarstvo v seredine XVI v. [Russian state in the middle of the $16^{\text {th }}$ century]. Moscow, $277 \mathrm{p}$.

Usachev, A.S. (2015). Ob istorii bytovaniya idei «Tret’yego Rima» v Rossii XVI v. [On the history of existence of the idea of "Third Rome" in Russia of the 16 century ]. In Bulletin of Russian Sacred Tikhonov State University (PSTGU). Ser. 2: History. The Russian Orthodox Church history, 3 (64), 9-17.

Uspenskiy, B.A. (1998). Tsar' i patriarkh. Kharizma vlasti v Rossii (Vizantiyskaya model' i yeye russkoye pereosmysleniye). [Tsar and Patriarch. Charisma of power in Russia (the Byzantine model and its Russian rethinking)], Moscow, $680 \mathrm{p}$.

\title{
К проблеме изучения отражения идентичности в русском искусстве XVI-XVII вв.
}

\author{
Н.В. Парфентьева \\ Южно-Уральский государственный университет \\ Россия, 454080, Челябинск, ул. Ленина, 76
}

В статье раскрываются пути изучения особенностей репрезентации в отечественном искусстве XVI-XVII вв. стержневых концептов русской культурной идентичности, рассматриваемой в ее непрерывном динамическом и диалектическом развитии на ключевых этапах формирования и трансформации. Актуальность исследования обусловлена тем, что среди значительного числа трудов по проблемам отечественного искусства Позднего Средневековья и начала Нового времени отсутствуют специальные научные работы, в которых указанная тема рассматривалась бы в качестве основной. Наиболее важно установить, что является фундаментальным (архетипическим) основанием культурной идентичности, как она трансформировалась в переломные периоды истории. Автор предлагает методы и подходы для решения проблемы. Одним из значимых научных подходов в его реализации является комплексность исследования. Она состоит в осмыслении устойчивого национально-исторического ядра культурной идентичности и его воплощения в искусстве изучаемого периода на всех хронологических этапах. Фактор идентичности выделяется как решающее звено, синтезирующее действие различных детерминант развития искусства. Добавляют новизны в изучении темы авторские концепты отражения идентичности в искусстве и использование иелого ряда авторских методов. Это позволяет автору выявить семантико-стилистические формулы воплощения идентичности в творчестве мастеров. Обосновывается применение интертекстуального метода выявления сущностных основ культурной идентичности, метода текстологического структурно-формульного анализа музыкально-гимнографических произведений средневекового искусства, элементно-структурного метода изучения орнаментики памятников книжно-рукописного искусства. Решение поставленной проблемы дополнит современные научные представления о культурной идентичности в искусстве и духовной культуре России.

Ключевые слова: культурная идентичность, русское искусство, русификация византийского наследия, русское Позднее Средневековье, Иван Грозный, научные методы и подходы.

Научная спещиальность: 24.00.00 - культурология. 